\title{
Bloques de hormigón ligero con áridos reciclados de EVA: una contribución a la eficiencia térmica de paredes exteriores de edificios
}

\section{Lightweight concrete blocks with EVA recycled aggregate: a contribution to the thermal efficiency of building external walls}

\author{
A. B. De Melo(*); E. P. Silva(*)
}

Recepción/Received: 1-XII-12

Aceptación/Accepted: 14-V-13

\section{RESUMEN}

Las regiones con una gran producción de calzado sufren impactos ambientales derivados de la generación de residuos durante la producción de plantillas y suelas. Investigaciones realizadas en Brasil han demostrado la viabilidad técnica para el reciclaje de estos residuos, especialmente el Etileno Vinil Acetato (EVA), como agregado ligero en la fabricación de bloques de hormigón no estructurales. Este trabajo presenta una evaluación del rendimiento térmico, con mediciones de la variación de la temperatura en pequeñas paredes $\left(1 \mathrm{~m}^{2}\right)$ construidas con diversos materiales, incluyendo algunos tipos de bloques EVA y ladrillos de cerámica. Las pruebas demostraron actuaciones térmicas eficientes para las muestras con bloques EVA. Estos resultados y cálculos adicionales contribuyen con un aporte de valor añadido al bloque EVA, considerando que existen buenas expectativas del componente, con una nueva propuesta de geometría, pudiendo contribuir a la eficiencia energética de edificios, especialmente por su adecuación a la mayoría de las regiones bioclimáticas brasileñas.

Palabras clave: residuos; bloque EVA; rendimiento térmico; pequeñas paredes.

\section{ABSTRACT}

The regions with lots of shoe production suffer environmental impacts from waste generation during manufacturing of insoles and outsoles. Research conducted in Brazil has demonstrated the technical feasibility to recycle these wastes, especially Ethylene Vinyl Acetate (EVA), as lightweight aggregate, in the production of non-structural cement blocks. This article presents an evaluation of thermal performance with measurements of temperature variation in mini walls $\left(1 \mathrm{~m}^{2}\right)$ built with different materials, including various kinds of EVA block and ceramic bricks. Tests have shown efficient thermal performance for masonry blocks with EVA. These results and supplementary estimates contribute to add value to the EVA block, considering that there are good expectations that the component, with the new geometry proposed, can contribute to the energy efficiency of buildings, highlighting its suitability to most Brazilian bioclimatic regions.

Keywords: waste; EVA block; thermal performance; small walls.

(*) Universidad Federal de Paraíba, João Pessoa (Paraíba, Brasil)

Persona de contacto / Corresponding author: aluisiobmelo@hotmail.com 


\section{INTRODUCCIÓN}

El déficit de vivienda en Brasil y la gran generación de residuos sólidos que dañan el medio ambiente destacan la necesidad de nuevas técnicas que combinan la sostenibilidad, la comodidad y bajos costes de producción para las construcciones. Entre estas industrias, la del calzado, que utiliza Etileno Vinil Acetato (EVA), y la construcción civil, que explota muchos recursos naturales, se consideran sectores que generan grandes cantidades de residuos sólidos.

En la industria del calzado, durante la fabricación de los productos, son generados inevitables residuos debido a recortes de planchas de EVA para obtener los formatos deseados. Del total de residuos generados, sólo un $20 \%$ se reutiliza en el proceso de producción de nuevos calzados debido a las limitaciones de sus características físicas. Por lo tanto, la solución a un destino adecuado del restante de los residuos ha sido objeto de preocupación, llevando a la búsqueda de una alternativa para el destino más común, que es la utilización del potencial de energía de los restos de EVA para alimentar los hornos de las industrias de cemento. Es sabido que estos residuos tienen un gran potencial de utilización como agregados ligeros, reemplazando a los áridos naturales en la fabricación de productos alternativos. El residuo de EVA es un material de baja densidad, gran capacidad de deformación, tiene buenas características térmicas y acústicas, es estable, inerte y no susceptible a los hongos (1).

En la búsqueda de alternativas para el destino de los residuos de EVA se ha desarrollado una amplia investigación en Brasil con bloques que emplean estos residuos para el uso en albañilería no estructural. Estos estudios intentan establecer la resistencia a la compresión mínima aceptable para el prefabricado. El mejor resultado que combina una mayor incorporación de EVA y menor consumo de cemento Portland en la producción de estos bloques no estructurales $(39 \mathrm{~cm} \times 19 \mathrm{~cm} \times 9 \mathrm{~cm}$ ) fue obtenida con la dosificación 1:5 (en volumen), con 60\% de EVA sustituyendo a los áridos naturales, logrando una resistencia a la compresión de $1,3 \mathrm{MPa}$ (2) a los 28 días para el bloque EVA.

Para determinar la resistencia mecánica de estos bloques también se llevaron a cabo evaluaciones de las cargas y de los impactos en las paredes del prototipo construido con bloques EVA, a través de varias pruebas (impactos del cuerpo blando y duro, solicitaciones transmitidas por cierres repentinos de puertas y cargas perpendiculares $^{1}$ ) que pretendían simular situaciones accidentales

1 verificación del comportamiento de la acción de cargas suspendidas, como la adición de una balda colgada en la pared.

\section{INTRODUCTION}

The housing deficit in Brazil and the great generation of solid wastes that damage the environment highlight the need for new techniques that combine sustainability, comfort and low cost of production for buildings. Among these industries, footwear industry, that uses Ethylene Vinyl Acetate (EVA) and construction industry, that explores many natural resources, are considered sectors that generate large quantities of solid waste.

In footwear industry, during the manufacture of products, unavoidable wastes are generated because of the cutting of EVA boards to obtain the intended formats. These residues are partially (about 20\%) recycled in the production process itself, due to the limitations of their physical characteristics. For this reason, the solution to an appropriate destination of these wastes has been the subject of concern, seeking an alternative to the most common destination that has only been taking advantage of the energy potential when the EVA residues is used to feed the ovens of cement industries. It is known that such wastes have great potential to be used as lightweight aggregates, in substitution of natural aggregates in the production of alternative products. It is a waste with low density, large deformation capacity, good acoustic and thermal characteristics, stable, inert and non-susceptible to fungus (1).

In the search for alternatives to the destination of the EVA waste has been developed extensive research in Brazil on blocks containing this residue for use in nonstructural masonry. These studies seek to establish the strength to the minimum acceptable compressive to the precast proposed. The best result that combines greater incorporation of EVA and lower consumption of Portland cement in the production of these non-structural blocks (39 cm $\times 19 \mathrm{~cm} \times 9 \mathrm{~cm}$ ) was obtained with the dosage 1:5 (in volume) with 60\% EVA substituting the natural aggregate, achieving a compressive strength at 28 days to the block EVA equal to $1.3 \mathrm{MPa}$ (2).

To determine the mechanical strength of these blocks, it was performed evaluations of loads and impacts on the walls of the prototype built with EVA blocks, through various tests (impacts of soft and hard body, requests transmitted by sudden closures of door and loads from suspended piece ${ }^{1}$ ) that tried simulate accidental situations and normal use of a building (3). The results

1 verification of behaviour under action of suspended loads, such as putting up a shelf, wall mounted. 
y la utilización normal de un edificio (3). Los resultados mostraron que el valor de 1,2 MPa para el bloque EVA propuesto (sin función estructural) es suficiente como resistencia a la compresión mínima, dando un buen desempeño a las paredes probadas.

A partir de estos estudios, que permiten el uso de bloques EVA en albañilería no estructural, es importante medir una posible mejora del bienestar térmico proporcionado por dicho material. Por lo tanto, caracterizar el comportamiento térmico del bloque EVA propuesto como componente no convencional es el propósito de la presente investigación que ha levantado la expectativa de que el componente pueda contribuir con la eficiencia energética en edificios.

Es sabido que (4) conciliar la posibilidad de disfrutar de la ventaja de una menor conductividad térmica y el cumplimiento del requisito mínimo de resistencia en la producción de hormigón ligero es un desafío. Seguramente, esta compatibilización es uno de los objetivos cuando se trabaja con bloques de EVA, buscando satisfacer los requisitos de una albañilería no estructural.

La presente investigación está basada en el estudio (5) que comparó el comportamiento térmico de paredes hechas con bloques de hormigón convencional, ladrillos de cerámica ( 8 agujeros) y bloques de hormigón ligero (con la incorporación de diferentes proporciones de EPS - poliestireno expandido- en su mezcla). Las dos caras de las paredes estudiadas sufrieron diferencias de temperatura importantes durante la recogida de datos, realizadas en cámara térmica. Tal como se esperaba, la mayor diferencia de temperatura media $\left(25,3^{\circ} \mathrm{C}\right)$ entre los dos lados de las muestras se observó en la pared construida con bloques de EPS, que tiene más baja densidad $\left(1.065 \mathrm{~kg} / \mathrm{m}^{3}\right)$.

Los resultados de este estudio (5) son coherentes con el hecho de que la conductividad térmica del aire es menor que la matriz del material y por lo tanto la capacidad aislante de los materiales es proporcional a la porosidad (con poros pequeños y cerrados), reduciendo al mínimo la transmisión de calor por convección en el interior del material $(6,7)$. Así pues, la mayor capacidad aislante de los bloques con incorporación de EPS (5) es coherente con su mayor porosidad, densidad más baja y en consecuencia, con una menor conductividad térmica.

Otro estudio (8), de interés en esta investigación, evaluó la conductividad térmica para bloques de hormigón (39 $\mathrm{cm} \times 19 \mathrm{~cm} \times 19 \mathrm{~cm}$ ), con dosificación 1:1:2 (cemento: arena: grava) con sustitución parcial de la arena por partículas de goma de neumático. También ha sido evaluada la sustitución de cemento Portland por cenizas volantes showed that the value of 1.2 MPa to the EVA block proposed (without structural function) is sufficient as a minimum compressive strength, due to the good performance of the walls tested.

From these studies, which enable the use of EVA block in not structural masonry, it is important to measure the possible improvement on the thermal comfort provided by this material. Therefore, characterizing the thermal performance of the EVA block, proposed as an unconventional component, is the purpose of the current research that has generated expectations that the component can contribute to the energy efficiency of buildings, in which it will be used.

It is known that (4) reuniting the advantages of a lower thermal conductivity and a minimum requirement of strength in the lightweight concrete production is a challenge. Surely, this compatibility is a goal when working with EVA blocks, seeking to satisfy the requirements of a non-structural masonry.

This research is based on a study (5) comparing the thermal performance of walls made with conventional concrete blocks, ceramic bricks (8 holes) and lightweight concrete blocks (with the addition of different proportions of EPS - expanded polystyrene - in its mix). The two faces of the walls tested experienced important temperature differences during the data collection performed in thermal chamber. As expected, the highest mean temperature difference $\left(25.3^{\circ} \mathrm{C}\right)$ between the two sides of the samples were observed in the wall built with the lower density EPS blocks $\left(1065 \mathrm{~kg} / \mathrm{m}^{3}\right)$.

The results of this study (5) are consistent with the fact that the air thermal conductivity is lower than that of the material matrix and therefore the insulating capacity of the material is proportional to its porosity (with small and closed pores) minimizing the transmission of heat by convection in its inner parts $(6,7)$. Thus, the greater insulating capacity of the blocks with incorporated EPS (5) is consistent with its higher porosity, lower density and a consequently lower thermal conductivity.

Another study (8) of interest to this investigation evaluated the thermal conductivity for concrete blocks $(39 \mathrm{~cm}$ x $19 \mathrm{~cm} \times 19 \mathrm{~cm}$ ), with dosage 1:1:2 (cement: sand: gravel) with partial replacement of sand particles with tire rubber grinding. The replacement of Portland cement by fly ash and silica fume has also been evaluated. The 
y humo de sílice. Los autores han demostrado que el uso de la goma ha reducido la conductividad térmica, destacando el efecto del aire atrapado dentro del material. El uso de sílice activo y ceniza volante también contribuyó a la reducción de la conductividad térmica del material. El mejor resultado ha sido alcanzado con la sustitución del $50 \%$ de arena por las partículas de goma y del cemento por el humo de sílice $(10 \%)$ y ceniza volante $(15 \%)$, consiguiendo una conductividad térmica de $0,61 \mathrm{~W} / \mathrm{m} . \mathrm{k}$.

El rendimiento del aislamiento térmico de los bloques de hormigón con hasta 70\% de goma de neumáticos desechados (en sustitución a la arena) ha sido también evaluado en otro estudio (9). Las mejoras resaltadas en el aislamiento térmico de los bloques propuestos han variado entre el 5 y $11 \%$, conforme la cantidad de goma utilizada. Según los autores, estos bloques de hormigón con goma de neumático triturada se comportan de manera similar a los bloques de hormigón producidos en autoclave.

Con el fin de desarrollar bloques de hormigón ligeros con un mejor rendimiento de aislamiento térmico se ha desarrollado un otro estudio (10), en el que los autores destacan que el uso de albañilería de alta resistencia térmica es importante en climas cálidos, donde las temperaturas pueden alcanzar altos niveles, especialmente en verano. Por ejemplo, en el área del Golfo de Omán (región cercana al Ecuador), las temperaturas en verano pueden alcanzar hasta los $60^{\circ} \mathrm{C}$. Para los autores, una albañilería con alta resistencia térmica se puede lograr mediante la construcción de paredes dobles utilizando bloques corrientes, o la construcción de muros sencillos hechos con bloques especiales con baja conductividad térmica. Esto puede resultar una reducción considerable de la demanda de electricidad para enfriar el interior de las edificaciones.

El grado de influencia de parámetros climáticos en los edificios depende, entre otras cosas, de cada región climática (11). Por lo tanto, el marco geográfico de los resultados de la caracterización del bloque EVA en este estudio está situado en la franja ecuatoriana, donde el clima es caliente seco/caliente húmedo. En regiones calientes y húmedas, son pequeños los cambios diarios y estacionales de la temperatura del aire y los niveles de humedad son generalmente altos. En este contexto, la refrigeración es el principal objetivo del confort térmico en diseño arquitectónico.

Antes de la aplicación de técnicas de enfriamiento pasivas, es importante prevenir el aumento de calor de las cargas apreciables de radiación solar que alcanzan el cerramiento (11). Directrices constructivas, utilizando la zonificación bioclimática brasileña (12), entre una serie de recomendaciones y procedimientos reglamentarios para albañilerías exteriores, en la mayoría de los casos proponen elementos verticales ligeros. Por lo tanto, la authors have shown that the use of rubber has reduced thermal conductivity, highlighting the effect of air trapped within the material. The use of active silica and fly ash has also contributed to reducing the thermal conductivity of the material. The best result was achieved when substituting $50 \%$ of the sand with rubber grinding and the cement with the silica fume (10\%) and fly ash (15\%), obtaining a thermal conductivity of $0.61 \mathrm{~W} / \mathrm{mk}$.

The thermal insulation performance of the concrete blocks with up to $70 \%$ rubber from discarded tires (replacing the sand) was also evaluated in another study (9). Highlighted improvements in thermal insulation of the proposed blocks have varied between 5 and 11\%, according to the amount of rubber used. As stated by the authors, these blocks of concrete with grinded rubber tire behave similarly to the autoclaved concrete blocks.

In order to develop lightweight concrete block with a better thermal insulation performance, another study has been developed (10), wherein the authors note that the use of high thermal resistance masonry is important in hot climates where temperatures can reach high levels, especially in summer. For example, in the Gulf of Oman (region by the Equator), summer temperatures can reach $60{ }^{\circ} \mathrm{C}$. For its authors, masonry with high thermal resistance can be achieved by building double walls using ordinary blocks, or simple walls made with special blocks with low thermal conductivity. This can result in a considerable reduction of the power demand for cooling the interior of buildings.

The degree of influence exerted by climatic parameters in buildings varies, among other aspects, in agreement with each climatic region (11). Therefore, the context in which this study will analyze the results for the characterization of EVA block is within the range of Ecuador, where the climate is dry warm to humid hot. For example, in hot and humid regions, the daily and seasonal fluctuations in air temperature are small and humidity levels are generally high. So, in this context, cooling is the main goal of thermal comfort in architectural project.

Before the application of passive cooling techniques, it is important to prevent heat gains arising from appreciable loads from solar radiation that reach the building cover (11). The guidelines constructive, using Brazilian bioclimatic zoning (12), among several recommendations and regulatory procedures for external walls, in most cases, there are only slight indications for vertical elements. Therefore, passive cooling through the choice of building 
refrigeración pasiva a través de la elección de componentes de construcción de albañilería con un rendimiento térmico adecuado es una estrategia deseable y esto eleva las expectativas para determinar la real contribución del bloque de EVA propuesto.

Este artículo analiza el rendimiento térmico de distintos tipos de bloques EVA, comparando con el rendimiento de los ladrillos cerámicos, que son los componentes más utilizados en la albañilería de los edificios de la región. También se hacen cálculos de rendimiento térmico en estas comparaciones.

\section{METODOLOGÍA}

Las pruebas para la verificación del comportamiento térmico de las pequeñas paredes $\left(1 \mathrm{~m}^{2}\right)$ se realizaron dentro de una cámara térmica (Figura 1), construida con uno de los tipos de bloques de EVA. Esta cámara tiene controles para asegurar el aislamiento entre las dos superficies de pequeñas paredes evaluadas (una de ellas expuesta a una fuente de calor). Para ello, la cámara se divide en dos espacios, uno calentado y otro frío, separados por una pared hecha en parte con los bloques aislantes que serán evaluados. La instrumentación para la medición de la temperatura media del ambiente en la cámara se hizo con la instalación de colgantes en el yeso de la guarnición, en distintos puntos relacionados con los ejes verticales y horizontales, teniendo en cuenta el volumen de los dos espacios contiguos.

Durante los ensayos fue utilizado como fuente de calor un dispositivo diseñado específicamente para este propósito, compuesto por una caja metálica que contiene 12 bombillas de $150 \mathrm{~W}$, que suman un total de $1.800 \mathrm{~W}$ de potencia instalada a una distancia de un metro $(1 \mathrm{~m})$ de la pequeña pared. components for masonry, with adequate thermal performance, it is a desirable strategy, and this generates expectations to determine what will be the contribution of the proposed EVA block.

This article analyzes comparatively the thermal performance of various kinds of EVA blocks, and makes a comparison between them and the ceramic bricks, which are the most common components of the masonry buildings in the region. Calculations are also made of thermal performance in these comparisons.

\section{METHODOLOGY}

The tests for verifying the thermal behavior of small masonry $\left(1 \mathrm{~m}^{2}\right)$ were performed inside a thermal camera (Figure 1), constructed with one of block types EVA. This thermal chamber has some control to ensure isolation between the two sides (one exposed to the heat source) of small masonry evaluated. For that, the chamber is divided into two spaces, one heated and the other cooled, and a part of the isolation divider between them is the small masonry to be evaluated. The instrumentation for measuring the average temperature inside the chamber was made with the installation of devices hanging from the ceiling of plaster, at variable points relating to horizontal and vertical axes, in the volume of two contiguous spaces.

During the tests, it was used as a heat source a device designed specifically for this purpose, consisting of a metal box containing 12 lamp (150 W) totaling $1800 \mathrm{~W}$ of power, placed at a distance of one meter $(1 \mathrm{~m})$ the small masonry.

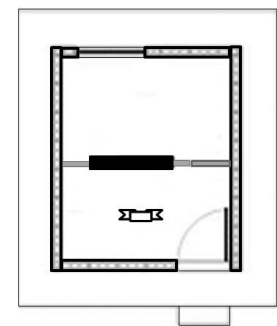

a) Plano de la cámara térmica con una pequeña pared (1 $\left.\mathrm{m}^{2}\right)$ situada en la parte central y la fuente de calor radiante colocada a $1 \mathrm{~m}$ de la superficie "A". I Test carried out inside the thermal chamber with a small masonry $\left(1 \mathrm{~m}^{2}\right)$ positioned in the central part and the radiant heat source placed at $1 \mathrm{~m}$ from the face " $A$ ".

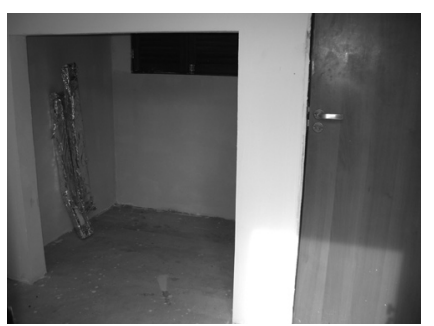

b) Partición en placas de yeso con espacio para la aplicación de la pequeña pared y la puerta (a la derecha) de acceso del espacio refrigerado (superficie "B"). / Dry wall partition with space for implementation of small wall and inner door (on the right) of refrigerated space access (face " $B$ ").

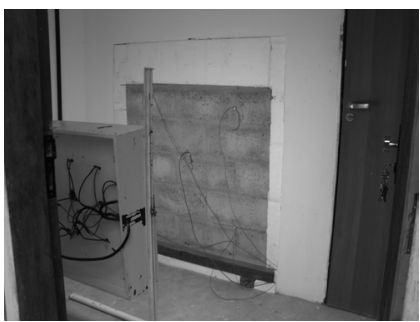

c) Complemento de espuma de poliestireno entre la muestra y el tabique de yeso, con la fuente de calor conectada. / Styrofoam completing between sample and dry wall partition, with the heat source turned on.

Figura 1. Prueba para la verificación de la variación térmica entre las superficies de las pequeñas paredes.

Figure 1. Test for verification of thermal variation between the faces of small walls. 
Los controles de temperatura en ambos espacios internos de la cámara térmica tienen como referencia los estudios $(5,6)$, que se llevaron a cabo en una cámara similar, garantizando que los dos lados de las muestras fueron objeto de las diferencias de temperatura importantes durante la recogida de datos.

Las pequeñas paredes fueron montadas con bloques de EVA (Figura 2) producidos con las dimensiones y las cantidades de EVA presentadas en la Tabla 1. En la Figura 2 se puede observar que los bloques EVA y de ladrillo cerámico tienen huecos internos en diferentes tamaños (la cámara de aire resulta de la propia geometría de los componentes). Por consiguiente, la contribución en el rendimiento térmico de la pequeña pared evaluada está relacionada con un mayor o menor volumen de aire que queda atrapado en cada tipo de bloque.
The temperature controls in both internal spaces in the thermal camera have, as reference studies $(5,6)$, which were conducted in a similar chamber, with the guarantee that the two faces of the samples were submitted to the significant differences in temperature during data collection.

For the execution of small masonry, EVA blocks were produced (Figure 2) with dimensions and quantities of EVA shown in Table 1. In Figure 2 it can be seen that the EVA blocks and the ceramic bricks have different sizes in internal voids (air chamber resulting from the geometry of the components). Therefore, the contribution to the thermal performance of the masonry evaluated is differentiated according to the higher or lower volume of air which remains trapped in each block type.

Tabla 1 / Table 1

Identificación de componentes utilizados en la preparación de pequeñas paredes. Identification of components used in the preparation of small walls.

\begin{tabular}{|c|c|c|c|c|}
\hline $\begin{array}{l}\text { Identificación I } \\
\text { Identification }\end{array}$ & $\begin{array}{l}\text { Dimensiones / Dimensions } \\
\text { largo } \mathrm{x} \text { ancho } \mathrm{x} \text { espesorl } \\
\text { length } \mathrm{x} \text { height } \mathrm{x} \text { width }(\mathrm{cm})\end{array}$ & $\begin{array}{l}\text { Cantidad de EVA / } \\
\text { Amount of EVA }\end{array}$ & $\begin{array}{l}\text { Masa de los bloques I } \\
\text { Mass of the blocks }\end{array}$ & $\begin{array}{c}\text { Componentes I } \\
\text { Components }\end{array}$ \\
\hline EVA $60 \% 9$ & $39 \times 19 \times 9$ & $60 \%$ & $6.7 \mathrm{~kg}$ & $\begin{array}{c}\text { Bloque EVA } A_{1} / \\
E V A_{1} \text { block }\end{array}$ \\
\hline EVA $60 \% 14$ & $39 \times 19 \times 14$ & $60 \%$ & $9.0 \mathrm{~kg}$ & $\begin{array}{c}\text { Bloque EVA } / \\
E V A_{2} \text { block }\end{array}$ \\
\hline${ }^{*}$ EVA $60 \% 12,5$ & $25 \times 25 \times 12,5$ & $60 \%$ & $11.0 \mathrm{~kg}$ & $\begin{array}{l}\text { Bloque } \mathrm{EVA}_{3} \text { I } \\
E V A_{3} \text { block }\end{array}$ \\
\hline${ }^{*}$ EVA $80 \% 12,5$ & $25 \times 25 \times 12,5$ & $80 \%$ & 7. $0 \mathrm{~kg}$ & $\begin{array}{c}\text { Bloque EVA }{ }_{4} / \\
E V A_{4} \text { block }\end{array}$ \\
\hline CER 9 & $19 \times 19 \times 9$ & - & $2.5 \mathrm{~kg}$ & $\begin{array}{l}\text { Ladrillo cerámico / } \\
\text { Ceramic brick }\end{array}$ \\
\hline
\end{tabular}

* Bloque EVA propuesto con dimensiones no convencionales (13) / EVA block proposed with unconventional dimensions (13).

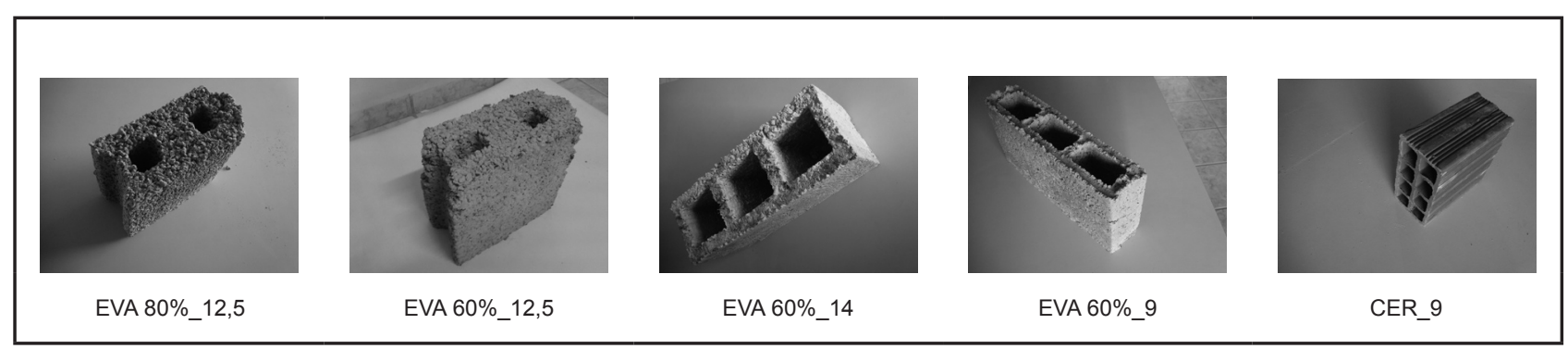

Figura 2. Tipos de bloques de EVA y ladrillos cerámicos utilizados en experimentos. Figure 2. Types of ceramic brick and EVA blocks used in experiments.

Por lo tanto, en el análisis de los datos, además de las comparaciones entre los resultados obtenidos con diferentes materiales (hormigón de EVA y bloques cerámicos), también se hicieron comparaciones con los resultados obtenidos entre bloques hechos con distintas geometrías y cantidades de EVA. En la Tabla 1 se puede notar que, además de las dimensiones, las masas de los componentes también son diferentes.
So, in the data analysis, it was done not only comparisons between the results obtained with different materials (ceramics and concrete EVA) but also comparisons with the results obtained among the EVA blocks, with different geometries and amounts of EVA. In Table 1, it can be seen that the dimensions and the masses of components are also different. 
Se realizaron dos pequeñas paredes con bloques EVA $60 \% 9$ y EVA $60 \% 14$, de dimensiones convencionales, fabricados con dosificación 1:5 (cemento: agregado; por volumen), con proporción de agregados $60 \%$ EVA $\left(D_{\max }=9,5 \mathrm{~mm}\right)$ y $40 \%$ arena $\left(D_{\max }=2,4 \mathrm{~mm}\right)$. Otras dos pequeñas paredes fueron construidas con los bloques EVA $60 \% 12,5$ y EVA $80 \% 12,5$, estos con dimensiones no convencionales (13), fabricados también con dosificación 1:5 (cemento: agregado; por volumen) y proporciones entre los agregados variables: uno con $60 \%$ EVA $\left(D_{\max }=9,5 \mathrm{~mm}\right)$ y $40 \%$ de arena; y otro con $80 \%$ EVA $\left(D_{\max }=9,5 \mathrm{~mm}\right)$ y $20 \%$ arena. Se utilizó el cemento Portland CP II F 32 y se adoptaran los controles de producción consolidados en investigaciones anteriores (3). La confección de los bloques EVA se hizo en laboratorio en máquina semi automática con vibración y prensado limitados. Una vez prensados, se hizo una curación húmeda (UR>95\% e T $=25^{\circ} \mathrm{C}$ ) de los bloques durante 24 horas llevándoselos en seguida a tanques de curación con agua saturada con cal por 28 días, al final obteniendo en los cinco ensayos realizados valores de resistencia a la compresión superiores a 1,35 MPa.

Posteriormente, con el resto de los componentes fabricados se construyeron pequeñas paredes, adoptándose como regla la realización de la instrumentación tres días después de la cura del mortero de asentamiento, instalando sensores de temperatura (termopares) directamente sobre la superficie de los bloques. La instrumentación de las muestras fue realizada con diez termopares tipo T (Cobre / Constantán) y se distribuyó como sigue: cinco termopares en la cara expuesta al calor (cuatro periféricos a una distancia de $20 \mathrm{~cm}$ de los bordes y un central) y otros cinco termopares dispuestos de manera similar en la cara opuesta (Figura 3). Los termopares utilizados (sensibilidad $41,5 \mu \mathrm{V} /{ }^{\circ} \mathrm{C}$; rango de temperatura de 0 a $350{ }^{\circ} \mathrm{C}$; rango del error estándar \pm $1,0{ }^{\circ} \mathrm{C}$ o $0,75 \%$ ) fueron calibrados en laboratorio, comprobándose una variación de temperatura desde $0,4{ }^{\circ} \mathrm{C}$ hasta $94,8^{\circ} \mathrm{C}$.
Two small masonries were executed with $60 \% 9$ EVA blocks and $60 \% 14$ EVA blocks, which are components with conventional dimensions and were manufactured with dosage of 1:5 (cement: aggregates, by volume), and the ratio of the aggregate $60 \%$ EVA $\left(D_{\max }=9.5 \mathrm{~mm}\right)$ and $40 \%$ sand $\left(D_{\max }=2.4 \mathrm{~mm}\right)$. Other two small masonries were executed with $12.5 \% 60$ EVA blocks and $12.5 \% 80$ EVA blocks, these proposals with unconventional dimensions (13), also manufactured with dosage of 1:5 (cement: aggregates, by volume), and the proportions between the aggregates were variables: one with $60 \%$ EVA $\left(D_{\max }=9.5 \mathrm{~mm}\right)$ and $40 \%$ sand, and another with $80 \%$ EVA $\left(D_{\max }=9.5 \mathrm{~mm}\right)$ and $20 \%$ sand. The Portland cement used was CP II F 32 and it was adopted production controls consolidated in previous studies (3). The molding of EVA blocks was made in the laboratory in semi-automatic machine with pressing and limited vibration. After their molding, they were taken to wet cure ( $\mathrm{RH}>95 \%$ and $T=25^{\circ} \mathrm{C}$ ) which continued for 24 hours, and then, placed in tanks of cure with water saturated with lime, until they are 28 days old, when in the test for compressive strength (five copies) it was obtained values higher than 1.35 MPa.

Then, the remaining components were fabricated and small masonries were constructed, the adopted rule was performing instrumentation, only after three days of cure of mortar, by placing temperature sensors (thermocouples) directly on the surface of the blocks. The instrumentation of the samples was done with ten thermocouples type " $T$ " (Copper / Constantan) and was distributed as follows: five thermocouples placed in face exposed to heat, so as to have a central one (No. 1) and four peripheral ones at $20 \mathrm{~cm}$ around the sample, another five thermocouples were placed on the other side in corresponding positions (Figure 3). The thermocouples (sensitivity $41.5 \mu \mathrm{V} /{ }^{\circ} \mathrm{C}$ temperature range of $0^{\circ} \mathrm{C}$ to $350{ }^{\circ} \mathrm{C}$; standard error range $\pm 1.0^{\circ} \mathrm{C}$ or $0.75 \%$ ) were calibrated in a laboratory, checking temperature variation from $0.4^{\circ} \mathrm{C}$ to $94.8^{\circ} \mathrm{C}$.

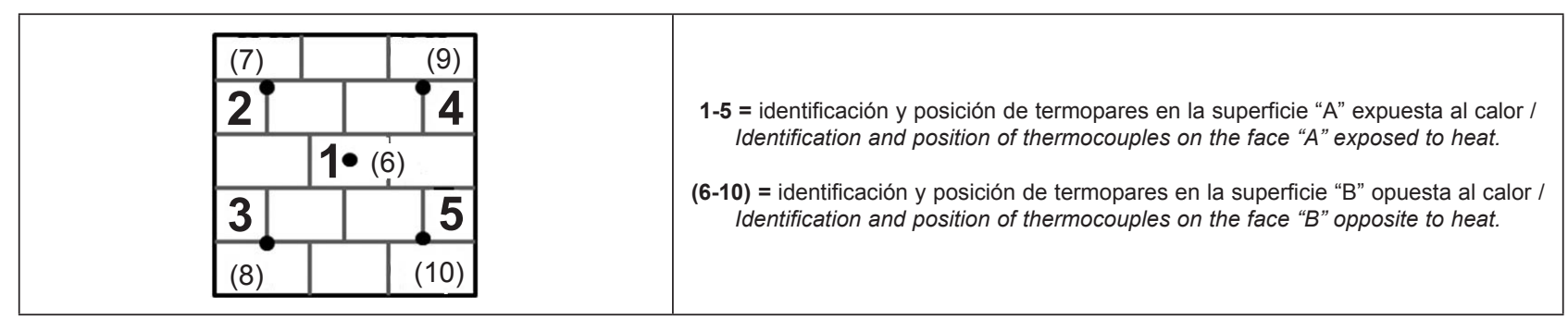

Figura 3. Diagrama de la posición de termopares en las superficies de las pequeñas paredes Figure 3. Schematic drawing of the position of thermocouples on the faces of small walls. 
Para la colocación de termopares en las superficies de los bloques fueron utilizados sujetadores de cable conectados a un sistema de adquisición de datos (Datalogger Almemo 2890-9) programado para registrar los valores de la temperatura cada minuto. Estos valores han sido sistematizados en una media aritmética por hora y presentados mediante gráficos de dispersión según la duración de la prueba (24 horas). La evaluación de pequeñas paredes hechas con ladrillo cerámico (CER 9) obtenidos en el mercado local se hizo adoptándose el mismo procedimiento de instrumentación.

En la sistematización de datos, también se consideran las temperaturas medidas en los cinco termopares para hacer medias finales por hora para cada cara de la pequeña pared. Con estas medias fueron determinadas las variaciones de temperatura entre las superficies expuestas y opuestas de cada muestra. La temperatura media general para cada cara de las muestras de prueba fue calculada sin tener en cuenta los datos registrados en las 4 horas iniciales, puesto que en este período las temperaturas en los termopares presentan variaciones, en más y en menos, en ambas caras de las muestras.

Para complementar el análisis del rendimiento de los materiales utilizados en la fabricación de bloques EVA fueron realizadas pruebas de conductividad térmica, basadas en la medición de la resistencia térmica por el método flujométrico en régimen constante, según la NBR 15220-5 (14). Esta norma brasileña fue redactada según la ISO 830. Con estos datos se llevaron a cabo cálculos de diversos parámetros (resistencia al calor, transmisión térmica, capacidad térmica y retraso térmico) importantes para caracterizar el desempeño de los componentes en cuestión, establecidos por la NBR 15220-2 (15). La prueba de conductividad térmica (equipo medidor de conductividad K30) se realizó con muestras en placas $(300 \times 300 \times 30 \mathrm{~mm})$ hechas con los mismos materiales y dosis utilizados en la fabricación de bloques EVA. Los cálculos de varios parámetros se llevaron a cabo teniendo en cuenta el flujo de calor perpendicular a los bloques sólo pegados, sin aplicación de mortero.

\section{RESULTADOS Y DISCUSIÓN}

\subsection{Variación de la temperatura de las muestras: estudio experimental}

Los datos recogidos de la temperatura media final en los ambientes de la cámara térmica durante los ensayos resultaron, para los dos espacios contiguos, en $44,6^{\circ} \mathrm{C}$ y $23,6{ }^{\circ} \mathrm{C}$, respectivamente. La temperatura media en el interior de la cámara térmica en los dos espacios
For the placement of the thermocouples on the surfaces of the blocks, it was used wire fixers and, after they were connected to a data acquisition system (datalogger Almemo 2890-9), which was programmed to record the temperature values at every minute. These values have been systematized by an arithmetic hours and presented using dispersion graphics according to the test duration (twenty-four hours). For the execution of small masonry using ceramic brick (CER 9), the components were purchased in the local market and adopted to the same procedures described above with respect to instrumentation.

In the systematization of the data, it is considered the temperatures measured in the five thermocouples to make the final averages per hour for each face of small masonries. With these averages, it was determined average variations in temperature between the exposed and opposite faces of each sample. The global average temperature for each face of the test samples was calculated without considering the data recorded in four hours early, considering that this is a period in which temperatures in thermocouples are still very varying up and down, according to the faces of samples.

To complement the analysis of the performance of the material used in the manufacture of the EVA blocks tests, it was performed thermal conductivity tests, based on the measurement of thermal resistance using the flowmetric method in stationary regime, according to NBR $15220-5$ (14). This Brazilian standard was developed in accordance with ISO 830. With this data, it was performed calculations of various parameters (thermal resistance, thermal transmittance, heat capacity and thermal lag) important to characterize the performance of the components in the analysis, as outlined in NBR 15220-2 (15). The test for thermal conductivity (for equipment Conductivity K30) was carried out with the samples in plates (300 mm x $300 \mathrm{~mm} \times 30 \mathrm{~mm}$ ) with the shaped material and the same dosages that are used in the manufacture of EVA blocks. The calculations of several parameters were performed considering the perpendicular heat flow only glued to the blocks without mortar.

\section{RESULTS AND DISCUSSION}

\subsection{Temperature variation through samples - an experimental study}

Data collected from the final average temperature in the thermal chamber environments during testing resulted, for the two adjacent spaces, in $44.6^{\circ} \mathrm{C}$ and $23.6^{\circ} \mathrm{C}$, respectively. The average temperature inside the thermal chamber in the two adjacent spaces was $27.8^{\circ} \mathrm{C}$ in the 
contiguos era de $27,8^{\circ} \mathrm{C}$ en la primera hora antes de comenzar las pruebas. Las temperaturas iniciales en las dos caras de cada pared ensayada estaban muy próximas de la temperatura media del interior de la cámara térmica, antes de comenzar las pruebas.

La Figura 4 presenta los resultados de las pequeñas paredes de mismo grosor y hechas con diferentes materiales. En este gráfico se puede observar que sólo después de cuatro horas la temperatura media en la superficie expuesta a la fuente de calor alcanza una temperatura de aproximadamente $40{ }^{\circ} \mathrm{C}$, con pequeñas variaciones en las horas siguientes. Al término de 24 horas de la prueba, la temperatura media en las superficies expuestas alcanzan $45^{\circ} \mathrm{C}$. En general, las fachadas Este y Oeste ejecutadas con albañilería en los edificios situados en regiones de latitudes cercanas al Ecuador reciben cargas significativas de radiación solar, alcanzando temperaturas superficiales exteriores de $50{ }^{\circ} \mathrm{C}(10)$. Así pues, las temperaturas simuladas en las muestras (caras expuestas) tienen coherencia con el contexto de la región de clima caliente. Al final de las 24 horas, las temperaturas en las caras expuestas de las paredes son prácticamente las mismas que la temperatura media del interior de la cámara térmica, en el espacio calentado.

En la Figura 4 se puede observar también que las superficies opuestas al calor alcanzan temperaturas medias finales entre $23{ }^{\circ} \mathrm{C}$ y $24^{\circ} \mathrm{C}$, con bloques EVA 60\% 9 y CER 9, respectivamente, lo que ya era esperado teniendo en cuenta que estaban en contacto con el medio sin fuente de calor de la cámara térmica, que presentó $23,6^{\circ} \mathrm{C}$ de temperatura media final. Durante las cuatro primeras horas, en la cara opuesta a la fuente de calor, las temperaturas registradas pasan de los $26^{\circ} \mathrm{C}$ iniciales a temperaturas inferiores manteniéndose más estables hasta el final de los ensayos. first hour before starting the tests. Initial temperatures on both sides of each wall tested were very close to the average temperature inside the heat chamber before beginning the tests.

Figure 4 shows the results of small masonry performed with components manufactured from different materials and widths. In this graphic, it can be seen that only the first four hours after the average temperature on the exposed face reaches a temperature of approximately $40{ }^{\circ} \mathrm{C}$, keeping up with little variation during the following hours. When it was twenty-four hours of testing, the average temperatures on exposed faces reach the same value, $45^{\circ} \mathrm{C}$. In general, the east and west areas of the masonry buildings located in regions with latitudes near the equator line receive appreciable loads of solar radiation, with surface temperatures reaching $50{ }^{\circ} \mathrm{C}$ (10). Then, the simulated temperatures in exposed faces of the samples are consistent with the context of the hot climate region. At the end 24 hours, temperatures on the exposed faces walls are practically the same as the average temperature inside the thermal Chamber, in the heated space.

In Figure 4 it can also be noticed that the opposed surfaces reach final heat average temperatures between $23{ }^{\circ} \mathrm{C}$ and $24{ }^{\circ} \mathrm{C}$, with EVA blocks 60\% 9 and CER 9, respectively, which was expected considering that they were exposed to the non-heated thermal camera, which presented a $23.6^{\circ} \mathrm{C}$ mean end temperature. During the first four hours, on the surface opposite to the heat source, temperatures reduce from the $26^{\circ} \mathrm{C}$ initial temperature, remaining more stable until the end of the tests.

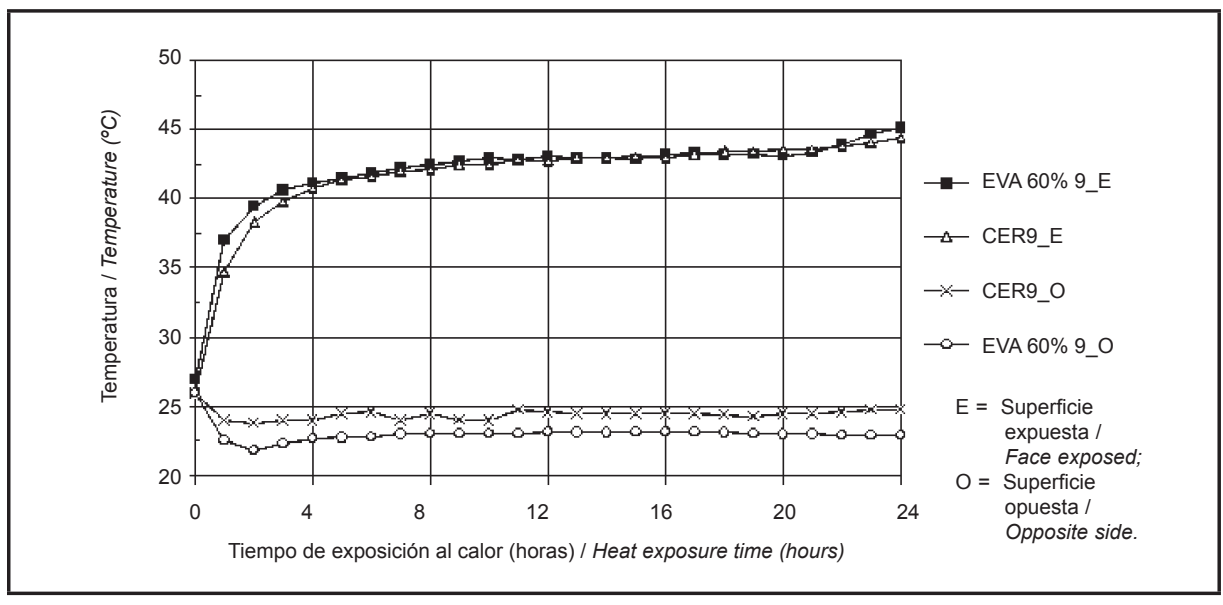

Figura 4. Resultados obtenidos con pequeñas paredes con diferentes materiales e igual espesor. Figure 4. Results obtained with small walls with different materials and same widths. 
De hecho, al iniciar las pruebas, con el accionamiento de las fuentes de calor y frío en cada espacio aislado en la cámara térmica, las temperaturas en las respectivas caras de las paredes experimentan elevación y reducción en las cuatro primeras horas, siguiendo la misma variación de la temperatura de los respectivos ambientes. Sin embargo, las superficies expuestas, hechas con bloques EVA $60 \% 9$ y CER 9, curiosamente experimentan una ligera subida de temperatura en las cuatro últimas horas de ensayo, lo que no se considera importante, teniendo en cuenta que las temperaturas finales de la superficie y del medio son prácticamente iguales (alrededor de $45^{\circ} \mathrm{C}$ ).

A continuación, los resultados parecen sugerir que, en pequeñas paredes a igualdad de espesor $(9 \mathrm{~cm})$, cuando comparamos los diferentes materiales de los componentes (EVA 60\% 9 y CER 9) se tiene un rendimiento ligeramente inferior del material cerámico. En este caso, debe considerarse que los volúmenes de la cámara de aire interna de los componentes son diferentes y que el contenido de $60 \%$ de EVA en el bloque de cemento influye en la mejora de su rendimiento térmico.

En la Figura 5 se presentan las variaciones en temperaturas para todas las muestras realizadas con bloques EVA (mismo material en comparación), teniendo en cuenta diferentes dimensiones y cantidades de EVA. El comportamiento observado es el mismo que en el caso anterior, cuando sólo después de las primeras 4 horas de ensayo se alcanza una temperatura más estable en las superficies expuestas al calor según las muestras de análisis.

Los resultados demuestran como la temperatura en la superficie expuesta a la fuente de calor, después de las primeras 4 horas, es similar en las muestras EVA 80\% 12,5 , EVA $60 \% 14$ y EVA $60 \%$ 9, que han alcanzado valores cercanos a $40^{\circ} \mathrm{C}$. Las máximas temperaturas finales
In fact, in the beginning of the tests, when the sources of heat and cold in each insulated thermal chamber were set, temperatures in the respective wall surfaces experienced increasing and decreasing for the first four hours, following the same temperature variation of the respective environments. However, the exposed surfaces made with EVA blocks 60\% 9 and CER 9 oddly felt a minor temperature rise in the last four hours, which is not considered important given that the final temperature on the surface and the environment are nearly the same (about $\left.45^{\circ} \mathrm{C}\right)$.

Then, the results seem to suggest that samples prepared with differences materials (EVA 60\% 9 and CER 9) have a slightly inferior performance to the ceramic material. In this case, it should be considered that the volume of the air chamber internally to the components is different and the concentration of $60 \%$ EVA in the cement block collaborates in improving its thermal performance.

Figure 5 shows the variations of temperatures for all samples performed with EVA blocks (the same material compared), considering different dimensions and amounts of EVA. The default behavior is the same as in the previous case, when only after the first four hours of test the temperature in one face exposed to heat is reached, which is slightly variable depending on the samples in analyze.

In fact, the temperature in the face exposed to the heat source after the initial four hours was similar in the samples EVA $80 \% 12.5$, EVA 60\% 14 and EVA 60\% 9, reaching values close to $40^{\circ} \mathrm{C}$. The final maximum temperatures with these same samples were also similar

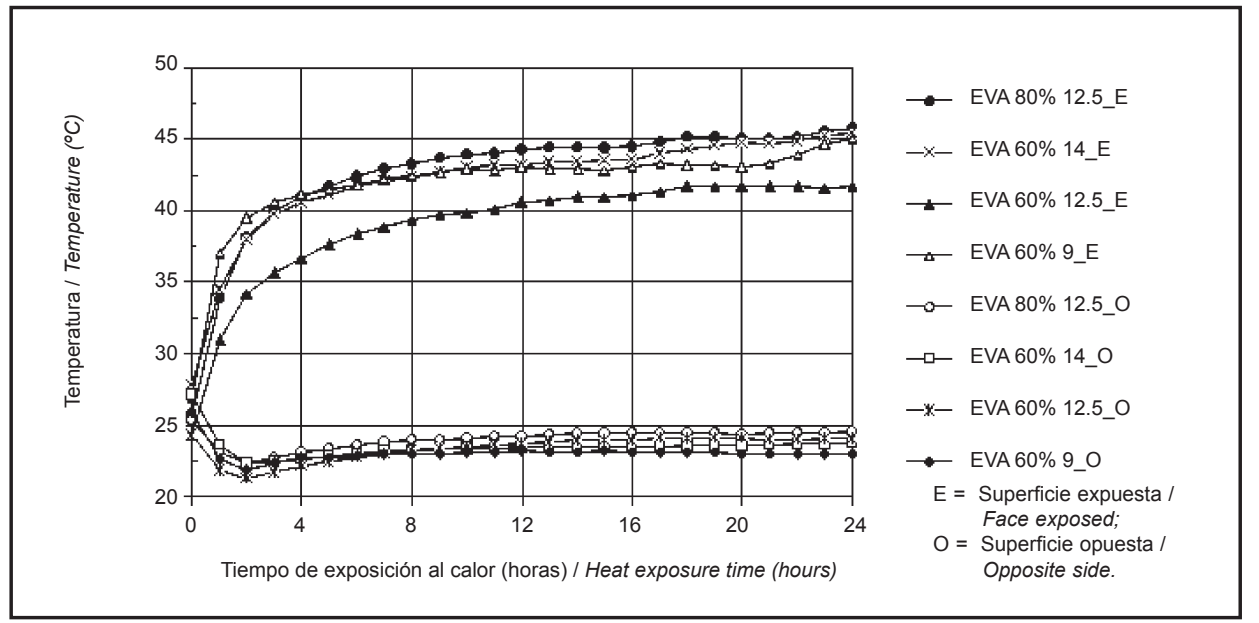

Figura 5. Resultados obtenidos con pequeñas paredes de bloques con diferentes dimensiones y cantidades de EVA. Figure 5. Results obtained with small walls with EVA blocks with different dimensions and quantities EVA 
con estas mismas muestras también fueron similares $\left(45^{\circ} \mathrm{C}\right)$, lo que sugiere rendimientos similares de los tres componentes, cada uno con diferentes geometrías y cantidades de EVA, sobre todo el grosor $(12,5 \mathrm{~cm}, 14$ $\mathrm{cm}$ y $9 \mathrm{~cm}$, respectivamente) y tamaños de vacíos de aire interno (cámaras de aire resultantes de la geometría). Los valores de medición en la cara expuesta al calor en la muestra EVA $60 \% 12,5$ son más bajos ( $3{ }^{\circ} \mathrm{C}$ inferiores), en comparación con las otras presentadas en la Figura 5, indicando que este componente no tenía el mismo rendimiento en la retención de calor en el lado caliente. De hecho, los resultados sugieren que la mayor retención de calor en la cara expuesta sucede con su mayor temperatura superficial. Por lo tanto, teniendo en cuenta los ensayos realizados, para una mayor retención de calor se espera una mayor distancia entre las curvas de la temperatura correspondientes en las caras expuesta y opuesta al calor.

Como consecuencia de los resultados, las tres primeras muestras (EVA 80\% 12,5, EVA 60\% 14 y EVA 60\% 9) parecen tener el mismo rendimiento de resistencia térmica, en la medida en que se produce una mayor diferencia entre las temperaturas medidas en las superficies expuestas y opuestas al calor, en comparación con otra muestra (EVA 60\% 12,5). En este caso, se puede deducir que la mayor cantidad de EVA en el bloque EVA $80 \%$ 12,5 , tiende a compensar el mayor grosor del bloque EVA $60 \% 14$, así como las diferencias de tamaño entre los huecos de aire en el interior de los componentes, que son más grandes en el bloque EVA $60 \% 14$. Se puede deducir también que la mayor cantidad de EVA en el bloque EVA $80 \% 12,5$, en cierta medida, compensa el mayor tamaño de los vacíos de aire del interior del bloque EVA $60 \% 9$.

Teniendo en cuenta que la conductividad térmica del aire es menor que la matriz del material se puede deducir que los vacíos de aire resultantes de la geometría de ladrillos y bloques (cámaras internas en componentes) y de la presencia de agregado de EVA desempeñan un papel importante en el resultado de la comparación entre las muestras evaluadas, reduciendo, de manera asociada la transmisión de calor por convección en el interior del material. Este análisis es coherente con los estudios (5-7) que han sido realizados con materiales similares.

Las comparaciones entre los resultados obtenidos para las temperaturas medias generales también sugieren que los bloques EVA 80\% 12,5, EVA 60\% 14 y EVA 60\% 9 tienen el mismo rendimiento (Tabla 2). Las variaciones de la temperatura media general entre las superficies de las muestras con estos bloques (EVA 80\% 12,5, EVA $60 \% 14$ y EVA $60 \%$ 9) son superiores $\left(1,5^{\circ} \mathrm{C}\right)$, en comparación con el ladrillo cerámico. Sin embargo, en este análisis deben tenerse en cuenta las diferencias de $\left(45^{\circ} \mathrm{C}\right)$, suggesting similar behavior for the three components, which have different amounts of EVA and geometries, especially widths (14 cm, $12.5 \mathrm{~cm}$ and $9 \mathrm{~cm}$ ) and sizes of internal air voids (air chambers resulting from geometry). The temperatures measured on the face exposed to heat in the sample are EVA $60 \% 12.5$ lowers compared to the other presented in Figure 5, which indicates that this component did not have the same performance on the retention of heat in the hot side. In fact, the results suggest that the increased retention of heat in the exposed face occurs because of its higher temperature. Therefore, considering the tests performed, for greater heat retention, a greater distance between the corresponding temperature curves of the surfaces opposed to the heat exposition is expected.

Thus, the three first samples (EVA 80\% 12.5, EVA 60\% 14 and EVA 60\% 9) appear to have the same performance from the viewpoint of heat resistance, in that resulted in the greatest difference between the temperatures measured in faces opposite and exposed to heat, compared with another sample (EVA 60\% 12.5). In this case, it can deduce that the greater amount of EVA present in $80 \% 12.5$ EVA block, tends to offset the greater width of the EVA block $60 \% 14$ and the size differences between the air voids within the components which are larger in EVA block $60 \%$ 14. It can also be deduced that this larger amount of EVA in the EVA block $80 \% 12.5$, it somehow compensates the larger size of the air voids inside the EVA block 60\% 9.

Taking into account that the thermal conductivity of air is lower than that of matrix material can be deduced that the air voids resulting from the geometry of the blocks and bricks (internal chambers in the components) play an important role in the comparison between samples, considering the presence of different internal volumes of air (which has greater thermal insulation capacity) for each component assessed. This analysis is coherent with studies (5-7) which have been carried out with similar materials.

The comparisons among the results obtained for general average temperatures also suggest that EVA blocks $80 \%$ 12.5, EVA 60\% 14 and EVA 60\% 9 have the same performance (Table 2). The variations of the general average temperature between the faces of the samples with these blocks (EVA 80\% 12.5, EVA 60\% 14 and EVA 60\% 9) are superior $\left(1.5^{\circ} \mathrm{C}\right)$, when compared to ceramic brick. But, in this analysis, it should be considered the differences in width among components compared (EVA 
Tabla 2 / Table 2

Las temperaturas medias generales $\left({ }^{\circ} \mathrm{C}\right)$ y sus variaciones, de acuerdo con cada lado de las pequeñas paredes. General average temperatures $\left({ }^{\circ} \mathrm{C}\right)$ and their variations, according to each side of the small walls.

\begin{tabular}{|c|c|c|c|}
\hline $\begin{array}{l}\text { Cara expuesta / } \\
\text { Face exposed }\end{array}$ & $\begin{array}{l}\text { Cara opuesta / } \\
\text { Opposite side }\end{array}$ & $\begin{array}{c}\text { Variación de la temperatura / } \\
\text { Temperature variation }\end{array}$ & $\begin{array}{l}\text { Pequeña pared probada I } \\
\text { Small walls tested }\end{array}$ \\
\hline 43.1 & 23.1 & 20.0 & $\begin{array}{c}\text { bloque EVA 60\%_9 / } \\
\text { EVA block 60\%_9 }\end{array}$ \\
\hline 43.6 & 23.5 & 20.1 & $\begin{array}{c}\text { bloque EVA } 60 \% \text { _14 / } \\
\text { EVA block } 60 \% \_14\end{array}$ \\
\hline 40.6 & 23.7 & 16.9 & $\begin{array}{c}\text { bloque EVA } 60 \% \_12.5 \text { / } \\
\text { EVA block } 60 \% \text { 12.5 }\end{array}$ \\
\hline 44.3 & 24.3 & 20.0 & $\begin{array}{c}\text { bloque EVA 80\%_12.5 / } \\
\text { EVA block 80\%_12.5 }\end{array}$ \\
\hline 43.0 & 24.5 & 18.5 & $\begin{array}{l}\text { ladrillo cerámico CER_9 / } \\
\text { ceramic brick CER_9 }\end{array}$ \\
\hline
\end{tabular}

espesor entre los componentes en comparación (bloques de EVA: $12,5 \mathrm{~cm}, 14 \mathrm{~cm}$ y $9 \mathrm{~cm}$; ladrillo cerámico: 9 $\mathrm{cm})$, además de las diferencias entre los materiales y el volumen de aire en el interior de ellos.

Al comparar los bloques EVA $60 \% 12,5$ y EVA $80 \% 12,5$, la diferencia entre la temperatura media general fue de $3,1^{\circ} \mathrm{C}$; en este caso sobresale la influencia de la cantidad de EVA, puesto que los dos bloques tienen el mismo grosor $(12,5 \mathrm{~cm})$ y geometría. Por lo tanto, si el bloque EVA $80 \% 12,5$ presenta una mayor capacidad de aislamiento térmico que el bloque EVA $60 \% 12,5$, compuesto por el mismo agregado EVA $\left(D_{\max }=9,5 \mathrm{~mm}\right)$, sin duda la mayor cantidad de EVA hizo que la primera (bloque EVA $80 \% 12,5$ ) tuviese mayor porosidad, lo que justifica su mejor rendimiento térmico.

Es importante destacar que el bloque EVA 80\% 12,5 experimenta situaciones desfavorable y favorable a su aislamiento térmico. Comparado con los otros bloques de EVA evaluados, el bloque EVA 80\% 12,5 tiene nueva geometría con menor vacío interior y menor volumen de aire atrapado, lo que es una situación desfavorable para el aislamiento térmico, mientras que el aire conduce menor calor que el material sólido. La situación favorable para el aislamiento térmico del bloque EVA $80 \% 12,5$, mientras que el mayor contenido de EVA conduce a la baja conductividad térmica, es que sólo con esse bloque se ha logrado utilizar más cantidad de EVA (80\%), que hizo el componente más ligero (sólo $7 \mathrm{~kg}$ ), sin reducir su resistencia a la compresión por valor inferior a 1,2 MPa, que es el límite propuesto (3).

\subsection{Cálculos de análisis complementarios para diversos parámetros térmicos}

Los resultados de pruebas de conductividad térmica para muestras hechas de cemento, arena y EVA en la proporción de $60 \%$ y $80 \%$, fueron $0,61 \mathrm{~W} / \mathrm{mK}$ y $0,34 \mathrm{~W} / \mathrm{mK}$, blocks: $12.5 \mathrm{~cm}, 14 \mathrm{~cm}$ and $9 \mathrm{~cm}$; ceramic brick: $9 \mathrm{~cm}$ ), and the differences between the materials and air volumes inside them.

When comparing the EVA blocks 60\% 12.5 and EVA $80 \%$ 12.5), the difference between average general temperatures started to be $3.1^{\circ} \mathrm{C}$, so in this case the influence of the amount of EVA is highlighted, considering that the two blocks have the same width $(12.5 \mathrm{~cm})$ and even volume of air internally. Therefore, considering that the EVA block $8012.5 \%$ showed a higher capacity of thermal insulation than the EVA block 60\% 12.5, which both were molded with the same aggregate EVA $\left(D_{\max }=9.5\right.$ $\mathrm{mm}$ ) and which have the same geometry, including same width $(12.5 \mathrm{~cm})$, certainly the greatest amount of EVA contributed to the first block (EVA 80\% 12.5) has higher porosity, which justifies its better thermal performance.

It is important to emphasize that, with EVA block $80 \%$ 12.5, there are unfavorable and favorable situations for its thermal insulation. Compared to others EVA blocks evaluated, the EVA blocks 80\% 12.5 has new geometry with lower void inside it and a lower volume of trapped air, which is a disadvantage for thermal insulation, whereas the air leads less heat than the solid material. The advantage for thermal insulation of EVA block $80 \%$ 12.5, whereas the highest content of EVA leads to lower thermal conductivity, is that only this block has been produced with the greatest amount of EVA (80\%), which made it the lightest component (only $7 \mathrm{~kg}$ ), without reducing their compressive strength to below 1.2 MPa, which is the limit value suggested (3).

\subsection{Complementary analysis with calculations for various thermal parameters}

The test results of thermal conductivity for the samples made with cement, sand and EVA in the proportions $60 \%$ and $80 \%$, were $0.61 \mathrm{~W} / \mathrm{m} . \mathrm{K}$ and $0.34 \mathrm{~W} / \mathrm{m} . \mathrm{K}$, 
Tabla 3 / Table 3

Valores de resistencia térmica total, transmisión térmica, capacidad térmica y retraso térmico calculados para todos los bloques EVA y ladrillos de cerámica.

Values for Total Thermal resistance, Thermal Transmittance, Thermal capacity and Thermal Delay calculated for all EVA blocks and ceramic bricks.

\begin{tabular}{|c|c|c|c|c|}
\hline Muestras / Samples & $\begin{array}{c}\text { Resistencia térmica total / } \\
\text { Total thermal resistance }(\boldsymbol{R T})\end{array}$ & $\begin{array}{c}\text { Transmisión térmica / } \\
\text { Thermal Transmittance }(\boldsymbol{U})\end{array}$ & $\begin{array}{c}\text { Capacidad térmica / } \\
\text { Thermal Capacity (CT) }\end{array}$ & $\begin{array}{c}\text { Retraso térmico / } \\
\text { Thermal Delay }\end{array}$ \\
\hline & $\mathbf{( m}^{\mathbf{2} . \mathbf{K}) / \mathbf{W}}$ & $\mathbf{W} /\left(\mathbf{m}^{2} . \mathbf{K}\right)$ & $\mathbf{k J} /\left(\mathbf{m}^{2} . \mathbf{K}\right)$ & Horas / hours \\
\hline CON 9* & $0.3012^{* *}$ & $3.3^{* *}$ & $105^{\star *}$ & $1.8^{* *}$ \\
\hline CER 9 & 0.4124 & 2.4 & 42 & 4.1 \\
\hline EVA 60\% 9 & 0.3735 & 2.7 & 64 & 2.1 \\
\hline EVA 60\% 14 & 0.4043 & 2.5 & 67 & 2.2 \\
\hline EVA 60\% 12.5 & 0.4064 & 2.5 & 148 & 3.6 \\
\hline EVA 80\% 12.5 & 0.5524 & 1.8 & 120 & 4.2 \\
\hline
\end{tabular}

* Bloques de hormigón con dimensiones convencionales $(39 \mathrm{~cm}$ x $19 \mathrm{~cm} \times 9 \mathrm{~cm}) /$ * concrete blocks with conventional dimensions (39 cm x $19 \mathrm{~cm}$ x $9 \mathrm{~cm})$. ** Valores de referencia presentados en NBR 15220-2 (15) / ** reference values presented in NBR 15220-2 (15).

respectivamente. Como se esperaba, la mayor cantidad de EVA presentó menor conductividad térmica, la cual es consistente con la afirmación de que esta propiedad está influenciada por la porosidad de cada material (6, 7). Los resultados muestran que el bloque EVA $80 \%$ 12,5 presentó mayor capacidad de aislamiento térmico que el bloque EVA $60 \% 12,5$. Como ambos tienen la misma geometría y espesor $(12,5 \mathrm{~cm})$, sin duda la mayor cantidad de EVA ( $80 \%$ vs. $60 \%$ ) hace que el bloque EVA $80 \% 12,5$ tenga mayores cantidades de huecos en su microestructura interna, debido incluso a la naturaleza porosa de las propias partículas de EVA. Este análisis es consistente con los resultados obtenidos para la conductividad térmica que fue menor en la muestra EVA 80\% 12,5 y justifica también su mejor rendimiento térmico. Este análisis es coherente con un estudio anteriormente realizado $(8,9)$, que evaluó la conductividad térmica para bloques de hormigón con dosificación 1:1:2 (cemento: arena: grava), y sustitución parcial de arena por las partículas de goma de neumático.

Los resultados de los cálculos de la resistencia térmica, transmisión térmica, capacidad térmica y retardo térmico se presentan en la Tabla 3 y son necesarios para complementar el análisis de las propiedades térmicas de los componentes utilizados en las albañilerías de los edificios. Todos los cálculos presentados fueron realizados para paredes con bloques recibidos sin morteros de unión entre ambas superficies, utilizando fórmulas básicas propuestas en la NBR 15220-2 (15). En estos cálculos se consideraron el tamaño de cada componente (incluyendo las dimensiones de cada cámara de aire) y los respectivos valores medios recomendados en la NBR 15220-2 (15) para la resistencia térmica superficial (interna y externa) y la resistencia térmica de la cámara de aire no ventilada. Las propiedades térmicas de materiales con valores conocidos de calor específico, densidad de masa aparente y conductividad térmica se adoptaron en el caso de bloques de hormigón y ladrillo de cerámica. respectively. As expected, the greater the amount of EVA resulted in lower thermal conductivity, which is coherent with the assertion that this property is influenced by the porosity of each material $(6,7)$. As seen previously, in fact, EVA block $80 \% 12.5$ showed higher capacity of thermal insulation than the EVA block 60\% 12.5. Since the two blocks have the same geometry and the same width $(12.5 \mathrm{~cm})$, certainly the most amount of EVA (80\% vs. $60 \%$ ) contributed to EVA block $80 \% 12.5$ has greater number of micro voids in its micro-internal structure, even due to the porous nature of the particles themselves of EVA. This analysis is coherent with the result obtained to thermal conductivity that was lower for the sample of EVA $80 \% 12.5$ and justifies its better thermal performance. This analysis also supports the studies (8, 9) which evaluated the thermal conductivity for concrete blocks (39 cm x $19 \mathrm{~cm} \times 19 \mathrm{~cm})$, with dose 1:1:2 (cement: sand: gravel) with partial substitution of the sand by tire rubber particles.

The calculation of the thermal resistance, thermal transmittance, thermal capacity and thermal delay are presented in Table 3 and are necessary to complement the analysis of the thermal properties of the components applicable in masonry of the buildings. All reported calculations were performed for bonded block walls without coating mortar on both surfaces, using basic formulas proposed in NBR 15220-2 (15). In these calculations, dimensions of each component were considered and adopted their respective average values recommended in NBR 15220-2 (15) for surface thermal resistances (internal and external) and thermal resistance of unventilated air chamber. The thermal properties of materials with known values for specific heat, specific gravity and thermal conductivity were adopted for the case of concrete block and brick ceramic. 
Considerando que cuanto más alto es el valor de la resistencia térmica y más bajo es el valor de la transmisión térmica, más aislante el material (10), cuando se comparan los resultados de la Tabla 3 se constata que el bloque EVA $80 \% 12,5$ tiene la más alta resistencia térmica $\left(0,5524 \mathrm{~m}^{2} . \mathrm{K} / \mathrm{W}\right)$ y la más pequeña transmisión térmica $\left(1,8 \mathrm{~W} / \mathrm{m}^{2} . \mathrm{K}\right)$ y por lo tanto se supone que presente el mayor obstáculo para el paso del calor. En el cálculo de la capacidad térmica (CT), que toma en cuenta el grosor del componente, el calor específico y la densidad aparente del material utilizado en la fabricación del mismo, el valor más alto (148 kJ /(m².K) se obtuvo para EVA $60 \%$ 12,5 . En estos cálculos se consideraron los valores de densidad, determinados experimentalmente (EVA 60\% = $1.422,6 \mathrm{~kg} / \mathrm{m}^{3}$ y EVA $80 \%=1.152,5 \mathrm{~kg} / \mathrm{m}^{3}$ ), dependiendo de la dosis empleada en la fabricación de los bloques. Para el calor específico se consideró el valor predeterminado $(1,0 \mathrm{~kJ} /(\mathrm{kg} . \mathrm{K}))$ adoptado para el hormigón.

Para el último parámetro, retraso térmico, se sabe que cuanto más alto, más tiempo tardará para que el medio analizado alcance la temperatura externa. Al comparar los resultados de las distintas muestras (Tabla 3), se destaca que el bloque EVA $80 \% 12,5$ presenta mayor retraso térmico (4,2 horas), prácticamente igual al valor encontrado para el ladrillo cerámico (CER 9).

El análisis debe tener en cuenta que los edificios deben cumplir las características que atiendan a los requisitos de rendimiento térmico, considerando la región bioclimática de su ubicación. La norma brasileña NBR 15575-4 (16) incluye los requisitos de paredes externas para 8 (ocho) regiones bioclimáticas. Para todas, son indicados valores de capacidad térmica (CT) mayor o igual a $130 \mathrm{~kJ} /\left(\mathrm{m}^{2} . \mathrm{K}\right)$ y de la transmisión térmica $(\mathrm{U})$ menor o igual a $2,5 \mathrm{~W} /\left(\mathrm{m}^{2} . \mathrm{K}\right)$, este último para cuando la absorción de la radiación solar en la superficie exterior de la pared sea superior a 0,6.

La NBR 15220-3 (12), además de establecer una zonificación brasileña ( 8 regiones bioclimáticas) incluye un conjunto de recomendaciones y estrategias constructivas en edificios de hasta 3 pisos para adaptación al clima. Entre estas recomendaciones, básicamente dos de las tres sirven para la mayoría de las regiones bioclimáticas: 1 - para el uso de muros exteriores ligeros (3 regiones bioclimáticas), se indica que la transmisión térmica $(U)$ debe ser menor o igual a $3,0 \mathrm{~W} /\left(\mathrm{m}^{2} . \mathrm{K}\right)$ y el retraso térmico inferior o igual a 4,3 horas; 2 - para el uso de muros exteriores pesados (con mayor inercia térmica; 3 regiones bioclimáticas) se indica una transmisión térmica $(U)$ menor o igual a $2,2 \mathrm{~W} /\left(\mathrm{m}^{2} . \mathrm{K}\right)$ y el retraso térmico mayor o igual a 6,5 horas. La tercera sirve para muros exteriores ligeros reflectores (2 regiones
Whereas the higher value of thermal resistance and lower of thermal transmittance, the material is more insulating (10), comparing the results of Table 3 it is clear that EVA block $80 \% 12.5$ has the highest thermal resistance $\left(0.5524 \mathrm{~m}^{2} . \mathrm{K} / \mathrm{W}\right)$ and has the lowest thermal transmittance $(U)$ value $\left(1.8 \mathrm{~W} / \mathrm{m}^{2} . K\right)$, and therefore it is expected that it has the greatest barrier to the passage of heat. In calculating the thermal capacity (TC), which takes into account the width of the component, the specific heat and specific gravity of the material used in the manufacture of component, the highest value (148 kJ) $\left(\mathrm{m}^{2} . \mathrm{K}\right)$ was obtained to the EVA block $60 \%$ 12.5. On these calculations were considered values of density, determined experimentally (EVA $60 \%=1,422.6 \mathrm{~kg} / \mathrm{m}^{3}$ and EVA $\left.80 \%=1,152.5 \mathrm{~kg} / \mathrm{m}^{3}\right)$, depending on the dosage used in the manufacture of blocks. For the specific heat was considered the standard measure $(1.0 \mathrm{~kJ} /(\mathrm{kg}.) \mathrm{K}))$ adopted for concrete.

For the last parameter analyzed, thermal delay, it is known that the higher it is, the longer it takes to the ambient reach the external temperature. By observing the results to the various samples (Table 3), stands out that the one calculated for the EVA block $80 \% 12.5$ has a higher thermal lag (4.2 hours), practically equal to the value found for the ceramic brick (CER 9).

In this analysis, it should be take into consideration that the buildings should gather characteristics that fulfill the requirements of thermal performance, considering the bioclimatic region of deployment of work. Brazilian standard NBR 15575-4 (16) highlights the requirements that should be satisfied for the outer walls, in accordance with 8 (eight) bioclimatic regions. This standard for all bioclimatic regions are indicated values to be attended for heat capacity (CT) greater than or equal to $130 \mathrm{~kJ} /$ $\left(m^{2} . K\right)$ and thermal transmittance $(U)$ less than or equal to $2.5 \mathrm{~W} /\left(\mathrm{m}^{2} . \mathrm{K}\right)$, the latter being the case when the absorptance to the solar radiation of the outer surface of the wall is greater than 0.6.

The NBR 15220-3 (12) besides establishing a Brazilian bioclimatic zoning (8 zones) includes a set of recommendations and constructive strategies for climate suitability of buildings up to three floors. Among these recommendations, it is highlighted basically two of them, which fit in most bioclimatic regions: 1 - to use of lightweight external walls (3 bioclimatic regions), it is indicated thermal transmittance $(U)$ less than or equal to $3.0 \mathrm{~W} /$ ( $\left.m^{2} . K\right)$ and thermal delay less than or equal to 4.3 hours; 2 -for use of heavy external walls (higher thermal inertia; three bioclimatic regions), it is indicated thermal transmittance $(U)$ less than or equal to $2.2 \mathrm{~W} /\left(\mathrm{m}^{2} . \mathrm{K}\right)$ and thermal delay greater than or equal to 6.5 hours. For use in reflective light external wall (2 bioclimatic regions), it is indicated thermal transmittance $(U)$ less than or equal 
bioclimáticas) e indica la transmisión térmica $(U)$ menor o igual a $3,6 \mathrm{~W} /\left(\mathrm{m}^{2} . \mathrm{K}\right)$ y el retraso térmico menor o igual a 4,3 horas.

Según los requisitos de la NBR 15575-4 (16), el bloque EVA $60 \% 12,5$ es el único que cumple con la capacidad de calor (CT) superior a $130 \mathrm{~kJ} /\left(\mathrm{m}^{2} . \mathrm{K}\right)$, mientras que los bloques EVA 60\% 9 y hormigón convencional CON 9 no cumplen la transmisión térmica (U) menor o igual a 2,5 $\mathrm{W} /\left(\mathrm{m}^{2} . \mathrm{K}\right)$. Al considerar la NBR 15220-3 (12), a la condición de muros exteriores, todos los bloques EVA y ladrillo cerámico cumplen las recomendaciones de transmisión térmica $(\mathrm{U})$ menor o igual a $3,0 \mathrm{~W} /\left(\mathrm{m}^{2} . \mathrm{K}\right)$ y el retraso térmico menor o igual a 4,3 horas. Por lo tanto, por cumplir dos normas mencionadas, el bloque EVA 60\% 12,5 parece tener el mayor potencial para ser utilizado en muros exteriores, incluso en muros ligeros reflectores, puesto que se adapta a las necesidades de rendimiento térmico para la mayoría de las regiones bioclimáticas brasileñas. El bloque EVA $80 \% 12,5$ parece conveniente para el uso en muros exteriores pesados (con mayor inercia térmica) aplicables en 3 regiones bioclimáticas con transmisión térmica $(\mathrm{U})$ menor de $2,2 \mathrm{~W} /\left(\mathrm{m}^{2} . \mathrm{K}\right)$, a pesar del retraso térmico ser de sólo 4,2 horas (debería ser mayor o igual a 6,5 horas). Para este mismo bloque EVA $80 \% 12,5$ el valor de la capacidad térmica (120 kJ/ $\left(\mathrm{m}^{2} . \mathrm{K}\right)$ ) está muy cerca del límite establecido en la NBR 15575-4 (16).

Por lo tanto, en todos los cálculos realizados en el análisis complementario, los bloques EVA 60\% 12,5 y EVA $80 \% 12,5$ parecen los más adecuados para aplicación en las diferentes regiones bioclimáticas brasileñas.

\section{CONCLUSIONES}

Los resultados experimentales presentados en este trabajo, muestran como cuando las superficies de las muestras en cuestión están supeditadas a diferencias significativas de temperatura, favorecidas por el aislamiento entre sus superficies en el interior de la cámara térmica, las variaciones de temperatura entre superficies (expuestas y opuestas al calor) tienden a ser mejor controladas. Asimismo, los comportamientos de las muestras que se evaluaron parecen presentar menos diferencias.

Teniendo en cuenta los resultados satisfactorios obtenidos, especialmente para nuevos bloques EVA con 12,5 $\mathrm{cm}$ de espesor, se puede resaltar que el potencial de recuperación de residuos de EVA para la fabricación de bloques no estructurales es prometedor, por la posibilidad de aporte de valor añadido al componente propuesto en su rendimiento térmico medido en experimentos to $3.6 \mathrm{~W} /\left(\mathrm{m}^{2} . \mathrm{K}\right)$ and thermal delay equal or less than 4.3 hours.

According to the requirements of the NBR 15575-4 (16), the EVA block $60 \% 12.5$ is the only one that meets more than $130 \mathrm{~kJ} /\left(\mathrm{m}^{2} . K\right)(C T)$ heat capacity, while that EVA blocks $60 \% 9$ and conventional concrete with 9 do not meet the heat transmission (U) less than or equal to $2.5 \mathrm{~W} /\left(\mathrm{m}^{2} . \mathrm{K}\right)$. In considering the NBR 15220-3 (12), to the condition of exterior walls, all EVA blocks and ceramic brick meet the recommendations of heat transmission (U) less than or equal to $3.0 \mathrm{~W} /\left(\mathrm{m}^{2} . \mathrm{K}\right)$ and the thermal delay less than or equal to 4.3 hours. Therefore, for addressing these two standards, the EVA block $60 \%$ 12.5 seems to have the highest potential for use in lightweight external walls, including the reflecting light ones, considering that it fits the requirements of thermal performance for most bioclimatic regions of Brazil. EVA Block $80 \% 12.5$ seems appropriate for use in heavy external walls (higher thermal inertia) applicable to three bioclimatic regions with thermal transmittance (U) less than $2.2 \mathrm{~W} /\left(\mathrm{m}^{2} . \mathrm{K}\right)$, despite the thermal delay is only 4.2 hours (it would need to be greater than or equal to 6.5 hours). For this same EVA block 80\% 12.5, the value of thermal capacity $\left(120 \mathrm{~kJ} /\left(\mathrm{m}^{2} . K\right)\right.$ is very close to the limit of the NBR 15575-4 (16).

Thus, in all calculations carried out in parallel analysis, EVA blocks 80\% 12.5 and EVA blocks 60\% 12.5, among those which were compared, they appear with greater possibilities of application in different bioclimatic regions of Brazil.

\section{CONCLUSIONS}

The experimental results presented here demonstrate that when the faces of test samples are submitted to temperature differences during data collection made possible by the isolation between its faces within the thermal chamber, the temperature variations between faces (exposed and opposite to heat) tend to be better controlled. Furthermore, the behavior of the samples that were evaluated seems to be less differentiated.

Considering the satisfactory results, especially for the new EVA blocks with width of $12.5 \mathrm{~cm}$, it is highlighted the potential for utilization of waste of EVA for manufacturing of non-structural blocks is promising, the possibility that one has to add value to the proposed component for its thermal performance measured in the experiments and in the supplementary calculations. 
y en cálculos complementarios. En este sentido, pueden señalarse algunos aspectos importantes para este componente:

- el bloque EVA 80\% 12,5, que cumple el requisito de funcionamiento mecánico para albañilería no estructural sugerido en estudios previos (3), ha obtenido un rendimiento térmico similar a lo de los bloques $60 \%$ 14 EVA y EVA $60 \%$ 9, que por su turno mostraron la mayor diferencia entre las temperaturas de las superficies (expuestas y opuestas al calor) de las pequeñas paredes evaluadas;

- la geometría, el espesor y el tamaño del vacío (cámara de aire) dentro del componente son variables que influyen mucho en su rendimiento térmico y fueron consideradas en el análisis de los resultados obtenidos. La influencia de la cantidad de EVA en la eficencia térmica fue comprobada por el buen rendimiento térmico del bloque EVA $80 \%$ con 12,5 en comparación con los otros evaluados;

- el vacío (cámara de aire) dentro del bloque EVA 80\% 12,5 es considerado pequeño en comparación con otros bloques, y tiene una influencia en su rendimiento térmico, lo que sugiere que se podrían realizar otros ensayos para cambiar el diseño del componente, mantener el equilibrio entre ligereza (con el uso del $80 \%$ de EVA en la composición del hormigón) y su rendimiento mecánico (resistencia a la compresión mínima de 1,2 MPa) para uso en albañilería no estructural.

Basado en la caracterización del rendimiento térmico de bloques EVA realizada y en situaciones de región de clima cálido, donde el enfriamiento es el principal objetivo del confort térmico en diseño arquitectónico, puede decirse que existen buenas expectativas de que el componente propuesto (bloques EVA 60\% 12,5 o EVA $80 \% 12,5$ ) pueda contribuir a la eficiencia energética de los edificios puesto que resulta adecuado a la mayoría de las regiones bioclimáticas brasileñas.

\section{AGRADECIMIENTOS}

A los laboratorios donde las pruebas fueron realizadas, por el apoyo (personal y material) en la ejecución de los estudios y a CAPES por la ayuda financiera, en el marco de la PRODOC, para la ejecución de esta fase de la investigación.
Consequently, some important aspects for this component can be identified:

- EVA block $80 \%$ 12.5, which satisfies the requirement of mechanical performance for non-structural mason$r y$, suggested in previous studies (3), also had good thermal performance that was similar to EVA blocks 60\% 14 and EVA blocks 60\% 9 that presented the greatest difference between the temperatures of the faces (exposed and opposite to heat) of small masonry evaluated;

- geometry, width and size of the void (air chamber) inside the component are variables that influence a lot in its thermal performance and were considered in the analysis of results. The influence of the amount of EVA was confirmed by the good thermal performance of the EVA block $80 \%$ with 12.5 compared to the other evaluated;

- the void (air chamber) inside the EVA block $80 \% 12.5$ is considered small compared to the other EVA blocks, which influence their thermal performance, suggesting that other evaluations could perform in order to change the design of the component, maintaining the balance between lightness (using $80 \%$ EVA in the composition of concrete) and its their mechanical performance (minimum compressive strength of $1.2 \mathrm{MPa}$ ) compatible for use in nonstructural masonry;

Based on the characterization of the thermal performance of the EVA blocks and performed in cases of hot climate region, where cooling is the main goal of thermal comfort in architectural design, it can be stated that there are good expectations that the proposed component (EVA block $60 \% 12.5$ or EVA block 80\% 12.5) can contribute to the energy efficiency of buildings, in which it will be used, taking into account that the adequacy for the majority of bioclimatic regions of Brazil.

\section{ACKNOWLEDGEMENTS}

To the laboratories where the tests have been performed, for the support (staff and equipment) in the realization of studies, and CAPES, for financial assistance at PROD$O C$, for the execution of this phase of the research.

\section{BIBLIOGRAFÍA / BIBLIOGRAPHY}

(1) Garlet, G.: "Aproveitamento de resíduos de EVA (ethylene vinyl acetate) como agregado para concreto leve na construção civil. Dissertação de Mestrado", p. 140, UFRGS, Porto Alegre (1998).

(2) Polari Filho, R. S.: "Contribuição ao processo de reciclagem dos resíduos da industria de calçados na construção civil: Bloco EVA uma alternativa às alvenarias das construções". Dissertação de Mestrado, p. 89, UFPB, João Pessoa (2005). 
(3) De Melo, A. B.; Lima Filho, M. R. F.: "Avaliação de desempenho estrutural de protótipo com paredes construídas com blocos EVA", Ambiente Construído, vol. 9, no 4 (2009), pp. 141-155.

(4) Ng, S. C.; Low, K. S.: "Thermal conductivity of newspaper sandwiched aerated lightweight concrete panel", Energy and Buildings, vol. 42, no 12 (2010), pp. 2452-2456. D.O.I.:10.1016/j.enbuild.2010.08.026

(5) Bezerra, C. A. L.: "Análise do desempenho térmico de sistema construtivo de concreto com EPS como agregado graúdo." Dissertação de Mestrado, p. 64, UFRN, Natal (2003).

(6) Silva, C. M. R. L.: "Análise técnico/financeiro de paredes externas em panos simples". Dissertação Mestrado, p. 185, IST- UTL, Lisboa (2007).

(7) Bénichou, N.; Sultan, M. A.: "Thermal properties of lightweight-framed construction components at elevated temperatures", Fire and Material, vol. 29, no 3 (2005), pp. 165-179. D.O.I.: 10.1002/fam.880

(8) Mohammed, B. S.; Hossain, K. M. A.; Swee, J. T. E.; Wong, G.; Abdullahi, M.: "Properties of crumb rubber hollow concrete block", Journal of Cleaner Production, vol. 23, no 1 (2012), pp. 57-67. D.O.I.:10.1016/j.jclepro.2011.10.035

(9) Turgut, P.; Yesilata, B.: "Physico-mechanical and thermal performances of newly developed rubber-added bricks", Energy and Buildings, vol. 40, no 5 (2008), pp. 679-688. D.O.I.:10.1016/j.enbuild.2007.05.002

(10) Al-Jabri, K.S.; Hago, A.W.; Al-Nuaimi, A.S.; Al-Saidy, A.H.: "Concrete blocks for thermal insulation in hot climate". Cement and Concrete Research, vol. 35, no 8 (2005), pp.1472- 1479. D.O.I.:10.1016/j.cemconres.2004.08.018

(11) Bitencourt, L; Cândido, C.: "Introdução a ventilação natural", p. 173, EDUFAL, Maceió (2008).

(12) Associação Brasileira de Normas Técnicas. NBR 15220-3: 2005. "Desempenho térmico de edificações - Parte 3: Zoneamento bioclimático brasileiro e diretrizes construtivas para habitações unifamiliares de interesse social" (Thermal performance in buildings Part 3: Brazilian bioclimatic zones and building guidelines for low-cost houses). Rio de Janeiro.

(13) Rocha, F. M. D. "Aproveitamento de resíduos sólidos industriais em materiais alternativos na perspectiva da construção seca: bloco EVA - intertravamento e racionalização das alvenarias". Dissertação de Mestrado, p. 107, UFPB, João Pessoa (2008).

(14) Associação Brasileira de Normas Técnicas. NBR 15220-5: 2005. "Desempenho térmico de edificações - Parte 5: Medição da resistência térmica e da condutividade pelo método fluximétrico". Rio de Janeiro.

(15) Associação Brasileira de Normas Técnicas. NBR 15220-2: 2005. "Desempenho Térmico das Edificações. Parte 2: Método de cálculo da transmitância térmica, da capacidade térmica, do atraso térmico e do fator solar de elementos e componentes construtivos". Rio de Janeiro.

(16) Associação Brasileira de Normas Técnicas. NBR 15575-4: 2012. "Edifícios habitacionais de até cinco pavimentos - Parte 4: Sistemas de vedações externas e internas". Rio de Janeiro. 